\title{
Stanisław Balbus
}

\section{Metodologie i mody metodologiczne we współczesnej humanistyce (literaturoznawczej)}

ABSTRACT. Balbus Stanisław, Metodologie $i$ mody metodologiczne we współczesnej humanistyce (literaturoznawczej) [Methodologies and methodological fads in the modern humanities, especially that concerning literary studies]. "Przestrzenie Teorii” nr 1, Poznań 2002, Adam Mickiewicz University Press, pp. 97-103. ISBN 83-232-1238-4. ISSN 1644-6763.

Methodology is a "visiting-card" of nomothematicity within every science, and even if a given discipline as a whole is not considered a nomothematic one. However, behind every methodology stands a definite epistemology thanks to which a revelation of the subject of considerations and at the same time of the studying object. Thus, methodology is an epistemological necessity and only in this sense may aspire to scientific aesthetics which - as proved by P. Dirac - is identical with real science.

Tytuł mojego wystąpienia budzić może pytanie, czy chodzi mi o to, że we współczesnej humanistyce (literackiej) za panowała moda na metodologie, czyli że metodologia naukowych procedur stanowi w niej przedmiot osobnego (jeśli nie pierwszoplanowego) zainteresowania. Czyli że za naukę w obrębie humanistyki uchodzi zwłaszcza aktywność, która w pierwszym rzędzie troszczy się o prawidłowość własnych procedur? Czy też idzie mi o to, że procedury takie przyjmowane są w niej na zasadzie mody, a więc przygodnie, tj. przypadkow ${ }^{1}$ ?

Bo wszak moda jest w zachowaniach ludzkich (i tylko ludzkich zresztą) tym rodzajem dość bezwzględnego i w miarę powszechnego przymusu (obligacji, opresji), który nie wynika z jakiejkolwiek koherentnej konieczności. Jest systemową wręcz determinacją o naturze gruntownie akcydentalnej. Moda, stając się globalizacją i „systematyzacją” przypadku, wcale przez to nie osiaga statusu, by tak rzec, systemowej konieczności. Wręcz przeciwnie. Jest zglobalizowanym apogeum przypadkowości.

Odwrotnie wszakoż ma się rzecz z modą na preferowanie metodologii w obrębie poszczególnych dyscyplin naukowych. Metodologia w

${ }^{1}$ Jest to tekst referatu wygloszonego na interdyscyplinarnym sympozjum „Konieczność i przypadek we współczesnej refleksji naukowej” (Uniwersytet Jagielloński, grudzień 2000 r.). 
obrębie każdej z nich stanowi bowiem ten poziom aktywności, na którym przebiega refleksja (i praca) zarówno nad jej koherencją wewnętrzną, jak i zewnętrzną integralnością w obrębie obszarów, wśród których egzystuje, choć sama może się nie czuć względem nich kompetentna przedmiotow o. To ostatnie oznacza, że dba ona (owa dyscyplina) o własne - wewnętrzne i zewnętrzne - uprawomocnienie, a zatem $w$ centrum uwagi i na froncie całej swojej budowli stawia konieczność. Metodologia jest w obrębie każdej dziedziny wiedzy wizytówką no motetyczności, nawet jeśli dana dziedzina, jako całość, za nomotetyczną nie uchodzi.

Pierwszy casus oznacza natomiast, że domena ostentacyjnie sięga po narzucającą się jej metodologię, o której nomotetycznej nobilitacji została przekonana, na zasadzie mody, czyli mniej lub bardziej przypadkowo (acz z - mniej lub bardziej - powszechnym aplauzem), aby niejako "formalistycznie" siebie samą „uprawomocnić", tj. zaprezentować jako „naukową" (metodologiczną właśnie) konieczność. Konieczność ugruntowana na fundamencie przypadku stanowi nie tylko prosty paradoks; tworzy i potęguje chaos, który jest przypadku metropolią.

$\mathrm{Z}$ drugiej wszakże strony - nadmierne eksponowanie poziomu metodologicznego dyscypliny, aczkolwiek nawet koherentne i uprawomocnione, może jednak w konsekwencji prowadzić do zachwiania jej wewnętrznej równowagi (a niekiedy i powagi), a to - mówiąc $w$ kolokwialnym uproszczeniu - poprzez przehandlowanie „prawdy” za „metodę” (a toż przysięgają uczeni „magis veritas propagetur”), czyli odsłonięcie własnej „bezprzedmiotowości”, również i w tym znaczeniu określenia, które bywa synonimem jałowości. Domena taka zachowuje jeden z głównych warunków naukowości, tj. metodologiczną koherencję i elegancję, „metodologiczną prawdę", ponieważ wlaściwym przedmiotem swoich badań i refleksji czyni w istocie samą siebie. W konkretnym przypadku więc przedmiotem badań literaturoznawczych okazuje się nie literatura, ale określona doktryna, czy zespół doktryn teoretycznoliterackich. Tego rodzaju przypadki (raz jeszcze przepraszam za słowo) są zbyt częste, żeby je tutaj wymieniać.

Z zewnętrznej perspektywy jawić się zatem może taka nauka wśród scjentycznych obszarów - jako przypadkowa, w tym sensie, że przygodna i "na dobrą sprawę" niekonieczna. Innymi słowy (jakby powiedziała Agata Christie): przypadek czai się wszędzie.

Tak więc tytuł mojego wystapienia tylko pozornie nie jest związany $\mathrm{z}$ tematem niniejszej konferencji. Fraza tytułowa mianowicie - oznajmiając, że współczesną humanistykę (literaturoznawczą) zdominowywują i metodologie, i mody metodologiczne, powiada w istocie, że jest ona dotkliwie rozpięta między przypadkiem a koniecznością, a także i to, że z tego obrazu wcale jeszcze sama przez się nie wynika biegunowa klarow- 
ność, tj. wyraziste rozróżnienie między plewą przypadku a ziarnem konieczności.

„Metodologiczne pytanie”, od którego ten wywód rozpocząłem, ma zatem odpowiedź oczywistą: interesuje mnie jeden i drugi (przepraszam za wyrażenie) przypadek metodologicznej mody. Panuje moda na poświęcanie szczególnej uwagi metodologicznym aspektom literaturoznawstwa. I panuje zgiełk metodologicznych licytacji, w którym atutem przetargu okazuje się kryterium mody (do czego zresztą nikt się głośno nie przyznaje, choć każdemu bodaj miło znaleźć się na topie mody).

Obydwa więc aspekty wydają mi się nader znamienne i interesujące, ale pierwszy jest znacznie poważniejszy i doniosły, przeto zasygnalizowawszy tę doniosłość, ze względów czysto technicznych odkładam jego rozważenie na inną okazję i zajmę się tutaj drugim.

\section{Metodologiczne mody. Zgiełk metodologicznej licytacji}

Nie stanowi on bynajmniej specyfiki polskiego życia literaturoznawczego, ale w Polsce (wskutek różnych, excusez le mot, przypadkowych układów okoliczności historyczno-politycznych) przedstawia się chyba bardziej imponująco niż za Zachodzie.

Zapanowała wreszcie (nie tylko zresztą w literaturoznawstwie) sytuacja zdrowego i naturalnego pluralizmu metodologicznego i teoretycznego. Oznacza to, że istnieją obok siebie różne (i niekoniecznie komplementarne) doktryny, z których każda urządza ten sam obszar przedmiotowy (tzn. literaturę) po swojemu i po swojemu prezentuje swój jego obraz jako „prawdziwy” (a przynajmniej „słuszny” i „przekonywający”). I wcale to przynajmniej w Polsce ostatniego 20-lecia) zauważalnego i doniosłego intermetodologicznego dialogu nie przynosi (aczkolwiek ciagle jeszcze panuje moda na intertekstualność). Po prostu dlatego, że różnice metodologiczne muszą przecież prowadzić do mówienia obcymi językami. Nacisk na poziom metodologiczny (i jego ostentacyjną oryginalność) wymusza zatem w konsekwencji komunikacyjny separatyzm. Zjawisko to istnieje od dawna i nie ma charakteru lokalnego. Ale w Polsce, jak powiadam, ma szczególnie dojmujący przebieg. Wcale nie dlatego, że 10 lat temu padł totalitaryzm i pluralizm demokratyczny zapanował także w naukach humanistycznych, a w literaturoznawstwie bodaj najwyraziściej. W Polsce już w latach 60 . nikt poważny nie brał poważnie marksistowskiego totalizmu w naukach humanistycznych (co innego w ekonomii). Dlatego jednak, w dużej mierze, że prawie nagła likwidacja znanej kurtyny, połączona (przypadkowo!) z niebywałą rewolucją informatyczną i informacyj- 
ną na świecie, otwierającą swobodny i bezpośredni dostęp do wszystkich naraz bibliotek świata, światowych konferencji i światowych ośrodków naukowych (co przedtem było przecież nie do pomyślenia), spowodowały przepływ także metodologicznych informacji (nie blokowany już nijak, a przecież ciągle chwytanych z paschalnym zachwytem po wielkim poście; stąd pewnie powszchne admiracje sakralnego przedrostka „post”).

Chcę po prostu taką oczywistość rzec: Postmodernizm - na temat którego jeszcze w 1992 roku pojawiła się w Polsce jedna jedyna książka (Bogdana Barana) - wniósł w ciągu kilku lat do naszego kraju jako niesłychanie czasem atrakcyjną nowość - wiele tych (znanych u nas wprawdzie, ale zwykle dość elitarnie) tendencji, które na Zachodzie dawno już straciły atrakcyjność, a niekiedy nawet ujawniły jałowość, a czasem nawet (jak część dekonstrukcjonizmu) dokonały publicznych aktów rewokacji. W każdym razie były już okrzepłe, jeśli nie uleżałe, i wchodziły niekiedy w fazy schyłkowe lub nabierały neutralnego dostojeństwa zabytków. Na nowym - polskim - gruncie, w kontekście rozkwitających w najlepsze tendencji, które na Zachodzie należały już niejako do „poprzedniej epoki”, stawały się nie tylko atrakcyjne, ale przybierały nobilitujące nabywcę znamiona ewidentnej nowoczesności (to słowo klucz humanistyki ostatniego 10-lecia), a jeszcze częściej (cudowny absurd słowotwórczo-semantyczny!) postnowoczesności (co trochę przypomina Orwellowskie „plus-dobry", a brzmi trochę jak pośmiertny).

Pora na konkrety. Najbardziej wyrazisty z nurtów (i metodologii) postmodernistycznych, dekonstrukcjonizm - który najmocniej, choć nie wyłącznie, ogarnął (jako poważna metod a badawcza) właśnie literaturoznawstwo - przywędrował na polskie uniwersytety, kiedy dojrzały strukturalizm ( $\mathrm{z}$ którego gruntownego przełamania się narodził jako jego negatywna kontynuacja) ciągle jeszcze miał trudności $\mathrm{z}$ osiedleniem się w polskich programach uniwersyteckich jako poważna i bynajmniej nie nowinkarska metodologia. Przywędrował. Zgodnie ze swoją naturą, i terminologią, ostentacyjnie się „uobecnił”, zaszczepił” i „rozplenił” oraz gruntownie przygłuszył swojego poprzednika; "przygłuszył” nie tylko już w sensie dekonstrukcjonistyczno-ogrodniczym, ale i pierwotnym, akustycznym. Nie rozegrał się w Polsce między tymi kierunkami żaden poważny i płodny spór metodologiczny. W ogromnej liczbie przypadków konwersji nastąpiła po prostu wymiana „metodologicznych” akcesoriów, czasami jedynie terminologii. Bywa, że aparycyjnie konsekwentna, metodologicznie jednak - a zatem i poznawczo - akcydentalna, przygodna.

$\mathrm{Z}$ bardzo nielicznymi, i przez to dobrze widocznymi, wyjątkami indywidualnymi (nie będę ich $\mathrm{z}$ oczywistych względów tutaj wymieniał) w żadnym polskim środowisku literaturoznawczym nie można było (i nie można nadal) zaobserwować takiego procesu ewolucji od założeń doktry- 
nerskiego strukturalizmu do kontekstualnej literackiej semiotyki, dokonującej otwarcia i dynamizacji autonomicznych strukturalnych modeli zjawisk kulturowych, jak w rosyjskiej „szkole dorpackiej”, czy we francuskim kręgu "Communications”, co w efekcie musiało prowadzić do „dekonstrukcji" strukturalistycznego myślenia, niezależnie od tego, czy przerodziło się w nową sformułowaną doktrynę i przyjęcie jej, jak we Francji, czy jak na uniwersytecie estońskim - nie. W Polsce wymieniono po prostu języki teoretycznoliterackie, tak jak ogół społeczeństwa zastapił makaronizmy rosyjskie makaronizmami amerykańskimi.

W takiej - nie powiadam: bezwyjątkowej, ale jednak znamiennej - sytuacji koegzystencja zachłannie zawłaszczonego dekonstrukcjonizmu, nie przemyślanego do faktycznie kryzysowych granic strukturalizmu, przybranego tylko w szaty strukturalnej semiotyki, a wywodzącego się ewidentnie $\mathrm{z}$ (także nie $\mathrm{w}$ pełni przemyślanego i rzetelnie przezwyciężonego) marksizmu; bardzo ekspansywnej, ale rzadko świadomej swego faktycznego filozoficznego zaplecza hermeneutyki, ustrukturalizowanej powierzchownie lub równie powierzchownie „umetafizycznionej” krytyki mitograficznej; uwikłanej w czysto polityczne ideologie (i równocześnie w psychoanalizę) krytyki feministycznej (a wszystko to w ostatnim „postmodernistycznym" dziesięcioleciu objawia się u nas w znacznej intensyfikacji) - więc sytuacja tego rodzaju koegzystencji "niedocieczonych" i poronnych wątków nie do faktycznego pluralizmu wiedzie, lecz do zgiełku przypadków, a w najlepszym razie do licytacji, o której społecznym wyniku decyduje nie racja myśli, lecz atrakcyjność terminologicznych ornamentów „ponowoczesności”, bo oczywiście w kraju wyzwolonym spod dominacji jednej ideologii nowoczesność to zbyt mało.

Coraz częściej zdarza mi się - i z nałogu, i z profesjonalnego obowiązku - lektura prac młodych, 30-, 40-letnich badaczy, a których nie tylko już sama dekonstrukcjonistyczna (czy postmodernistyczna) terminologia, ale tej proweniencji cale strategie badawcze, a zwłaszcza techniki narracyjne - skrywają, nieraz i bardzo udatnie, wyraźne nawyki myślenia w istocie strukturalistycznego, aliści w tej „metodologicznej” szacie i rzetelność owego strukturalistycznego substratu ulega podważeniu. Powstaje metodologiczna (i epistemologiczna) hybryda. Hybryda - a więc twór przypadkowy, zatem a-metodologiczny, jakkolwiek na powierzchni procedur badawczych, czy tylko narracyjnych, zachowuje ona pozory metodologicznej elegancji, a to by znaczyło koherencji, czyli w nomotetycznym sensie: konieczności.

A dzieje się tak dlatego, że owa koherencja - acz rzucająca się w oczy, i nieraz natrętnie - jest tutaj pozorna, tzn. obejmuje tylko wyższe piętra konstrukcji procedur badawczych, nie dotykając jej fundamentów. Obejmuje dystynktywne doktrynalnie techniczne czynności narracji, ale nie 
czynności myślowe, czyli inaczej: faktycznie poznawcze. Za określoną metodologia ( $w$ istotnym sensie tego słowa) stoi bowiem zawsze określona epis temologia. I ona dopiero w integralnym i pierwotnym spojeniu z systemem zabiegów techniczno-metodycznych i terminologiczno-narracyjnych tworzy metodologię jako metodę odsłonięcia (czy przynajmniej płodnej poznawczo ekspozycji) przedmiotu dociekań, a zarazem i sensownego odsłonięcia się dociekającego podmiotu (czyli samopoznania badacza). Nie można za pomocą języka filozofii Kantowskiej uprawiać psychoanalizy, ani w języku filozofii Husserla twórczo kontynuować Nietzscheańską filozofię interpretacji. Z czego nie należy wnioskować, że jestem przeciwnikiem badań interdyscyplinarnych. Ale interdyscyplinarność też winna być wyposażona w uczciwą metodologię i nie wolno jej zdawać się na metodologiczny przypadek.

Najprościej rzec ujmując: metodologia danej dyscypliny (czy też doktryny albo orientacji naukowej) stanowi epistemologiczna konieczność i w tym tylko sensie może rościć sobie pretensje do faktycznej wewnętrznej koherencji, czyli inaczej - jak to określał Paul Dirac naukowej estetyki, co dla niego oznaczało: rzeczywistej nauki. A nie uprawiał wszak estetyki, ani nawet teorii literatury, bo, jak wiadomo, nie pozostawiała mu na to czasu fizyka kwantowa.

Tak więc funkcja estetyczna to nie tylko szczególne naukowe odkrycie i przedmiot specjalnej troski twórców językoznawstwa i literaturoznawstwa strukturalnego, Jakobsona i Mukařovskiego. Dla twórców fizyki nowoczesnych (ale jeszcze bodaj nie po-nowoczesnej!), Einsteina i Diraca, stanowiła podstawową cechę dystynktywną nauki. A jej residuum stanowiła metodologia jako wykładnik epistemologicznej konieczności. A tym samym jeden $\mathrm{z}$ gwarantów poznawczej skuteczności. Czego odkrycie dodatnich elektronów, wyprowadzone z równań matematycznych, „empirycznie" dowodzi.

Zdaję sobie sprawę, że literaturoznawczy poststrukturalizm, a zwłaszcza dekonstrukcjonizm budzą tyleż nowinkarskiego (czy czasami po prostu arywistycznego) entuzjazmu, co przeciwnie: niechęci, a nawet drwin. I to nawet nie ze strony strukturalistów, którym te orientacje zdekonstruowały metodę (strukturaliści, jak powiedziałem, wykazują niekiedy dziwną skłonność do konwersji). Jeśli jednak dekonstrukcjonizm traktować poważnie (niekoniecznie stając się tym samym jego wyznawca, co dotyczy mówiącego te słowa) i jeśli poważnie traktować siebie, zabierając jakikolwiek głos w jego sprawie - to nie sposób przeoczyć, że dekonstrukcjonistyczne procedury i dekonstrukcjonistyczne narracje ugruntowane są w sposób oczywisty w filozofii dekonstrukcji. I jeśli nawet ta filozofia jest trudno czytelna, to przecież - po pierwsze właśnie - w Polsce, kraju postmodernistycznego entuzjazmu, ukazała się wyczerpująca i obszerna 
książka na ten temat; książka atoli częściej i pilniej bodaj czytana przez przeciwników metody, niż przez wielu jej entuzjastycznych adeptów. Po drugie - filozofia wyklucza strukturalizm tak gruntownie, jak - w odwrotnym porządku patrząc - Husserl wyklucza Nietzschego. Odległym ale silnym - patronem strukturalistów jest oczywiście Husserl. Odległym, właściwie głównie czasowo, antenatem dekonstrukcji - autor Wiedzy radosnej.

Można oczywiście - a nawet bezwzględnie należy - zapytać, skąd rzeczywiście, z racji jakiej niepozornej konieczności, nastąiła restytucja, czy aktualizacja, owej szkoły myślenia. Dlaczego nauczyciele myślenia dla formacji fin-de siecle'u znów odnajdywani są na linii Nietzschego. Albo zlakanizowanego Freuda. I na to odpowiedź nie wydaje się szczególnie trudna, choć nie jest też niewątpliwie prosta ani jednorodna. Wydaje się całkowicie współbieżna $\mathrm{z}$ odpowiedzią na jeszcze bardziej oczywiste pytania: dlaczego musiał (bo musiał) załamać się i zdekonstruować strukturalizm; gdyż przecież sam się zdekonstruował. Sami strukturaliści tę dekonstrukcję musieli rozpocząć i rozpoczęli. Ale tą koniecznością nie mogę się w tej chwili zajmować.

Powiem więc, zmierzając ku końcowi, tak w tymczasowym podsumowaniu: jeśli przejmuje się modne metody proceduralne dekonstrukcji, a zapomina o wskazanym tu wyżej zapleczu (i podobnego rodzaju antynomiach), wpada się właśnie w sidła przypadku, który jeśli nie prowadzi po prostu tylko do nieszkodliwego jawnego bełkotu, likwidującego wszelkie perspektywy i poznawcze, i komunikacyjne takich zabiegów i takich „naukowych" narracji, to w dalszej - poważnej już - konsekwencji tworzy się sobie wygodne, acz krótkotrwałe, azylum dla urlopowania z tak uprawianej „nauki” obowiązku myślenia. Albo - powiedzmy nieco bardziej elegancko: wyeliminowania $\mathrm{z}$ praktykowanej oto metodologii wszelkiej metodologicznej konieczności (czyli konieczności i zobowiązań epistemologicznych) przy pomocy technicznych narzędzi, mających służyć realizacji owej konieczności.

Akcydens proceduralny, przypadek (a chciałoby się powiedzieć: ciężki przypadek) metodologiczny, prezentujący się narracyjnie jako metodologiczna konieczność (bo z takim casusem mamy tu przecież do czynienia) - nie staje się przez to bynajmniej pokrewny Fatum, gdyż na to potrzeba by, aby przypadek faktycznie objawił się jako konieczność istotna. To tylko taka sobie komedia omyłek. I tak naprawdę nie ma się chyba o co martwić. Po prostu: takie sobie naukowe zabawy w dobie popkultury. 